\title{
Evaluation of incubation-based methods for estimating virioplankton production in estuaries
}

\author{
Rebekah R. Helton ${ }^{1}$, Matthew T. Cottrell ${ }^{2}$, David L. Kirchman ${ }^{2}$, K. Eric Wommack ${ }^{1,2, *}$ \\ ${ }^{1}$ Department of Plant and Soil Sciences, Delaware Biotechnology Institute, University of Delaware, 15 Innovation Way, \\ Newark, Delaware 19711, USA \\ ${ }^{2}$ College of Marine Studies, University of Delaware, 700 Pilottown Road, Lewes, Delaware 19958, USA
}

\begin{abstract}
Assessment of the role of viral lysis in aquatic microbial communities requires a robust means of estimating viral production (VP). Here, 3 incubation-based VP methods (fluorescently labeled viruses [FLV], dilution [DIL], and thymidine incorporation [TdR]) were evaluated in water samples from the Delaware and Chesapeake Bays. In Chesapeake Bay samples, average VP rates were 10-fold higher for FLV and DIL $\left(\sim 3\right.$ to $25 \times 10^{10}$ viruses $\left.\mathrm{l}^{-1} \mathrm{~d}^{-1}\right)$ than for TdR $\left(\sim 0.2\right.$ to $3 \times 10^{10}$ viruses $\mathrm{l}^{-1} \mathrm{~d}^{-1}$ ). Estimates of viral-mediated bacterial mortality (VMM) indicate that FLV overestimates VP in eutrophic waters, since $>100 \%$ of bacterial production (BP) would have been consumed through viral lysis. DIL and TdR VP methods gave more realistic estimates of VMM with respect to BP. The FLV method provides estimates of both VP and virus removal rates; however, it requires preparation of a viral tracer and twice as many microscopic enumerations as the DIL method. DIL was the least difficult and most efficient method; however, bacterial loss during vacuum diafiltration resulted in poor replicability. TdR gave similar VP estimates to DIL, but requires use of a large and poorly constrained conversion factor. With methodological improvements in bacterial cell recovery, DIL should be the most widely applicable method for estimation of VP in highly productive estuarine waters.
\end{abstract}

KEY WORDS: Viral production · Bacteriophage $\cdot$ Marine viruses $\cdot$ Marine microbial ecology

\section{INTRODUCTION}

Over $15 \mathrm{yr}$ ago, the fundamental understanding of the marine microbial food web was significantly altered with the discovery of high viral abundance. Models and empirical studies demonstrate that viral lysis can be a significant contributor to the flux of dissolved organic matter (DOM) from biomass in marine systems (Fuhrman 1992, Fuhrman \& Suttle 1993, Fuhrman \& Noble 1995). Changes in nutrient portioning (Middelboe et al. 1996) and the DOM pool have been discussed as possible biogeochemical impacts of viral lysis. Viral-mediated cell lysis remains a poorly constrained component within the global carbon cycle. Thus, finding a dependable means of estimating viral production (VP) is paramount to reaching this goal.

Estimating in situ VP has been addressed through a diverse group of methodologies, including indirect approaches such as viral decay or loss rates (Heldal \& Bratbak 1991, Suttle \& Chen 1992, Wommack et al. 1996), calculated virus-host contact rates (Waterbury \& Valois 1993, Suttle \& Chan 1994), and determining the frequency of visibly infected cells (FVIC) using transmission electron microscopy (TEM) (Proctor \& Fuhrman 1990, Bratbak et al. 1992, Weinbauer et al. 1993). Direct approaches to estimating VP rely on short-term incubation of water samples (ca. $12 \mathrm{~h}$ ) followed by an assay for either incorporation of radiolabel into virioplankton (Steward et al. 1992a,b) or epifluorescence microscopic-based enumeration of viruses. In general, direct, incubation-based methods require less reliance on assumptions and poorly constrained conversion factors (Binder 1999). Quantification of viral abundance is crucial for characterizing the potential role of viral infection within a given microbial community (Wommack et al. 1992), and is critical in the 
fluorescently labeled virus (FLV) and dilution (DIL) methods for estimating VP evaluated here.

FLV measures VP through the changing ratio of an added fluorescently labeled viral tracer to total viruses (Noble \& Fuhrman 2000). VP rates and simultaneous removal of viruses are determined using a mathematical approach similar to the isotopic dilution technique for measuring amino acids in seawater (Fuhrman 1987) and nitrogen dynamics in marine environments (Glibert 1982). DIL is the newest of the incubation-based VP methods (Weinbauer et al. 2002, Wilhelm et al. 2002). In this approach, virus-free water is used to dilute total viral abundance to ca. $10 \%$ of the original concentration in experimental incubations. The DIL technique allows VP rates to be monitored via changes in viral concentration over the course of 10 to $12 \mathrm{~h}$ incubations. Reduction of viral abundance is achieved by vacuum diafiltration, i.e. washing out free viruses by dilution with virus-free seawater. Subsequent production of viruses should result only from cells infected prior to dilution. VP is then estimated from the slope of the first-order regression line of viral abundance versus time. This is similar to the dilution approach developed by Landry (1993) for measuring phytoplankton growth and grazing.

The final VP technique evaluated here is based on incorporation of ${ }^{3} \mathrm{H}$-thymidine (TdR) into the viral fraction of seawater (Steward et al. 1992a,b). As it is a radiotracer assay, this method provides sensitive detection of VP; however, accurate determination of the number of viruses produced per mole of ${ }^{3} \mathrm{H}$-thymidine incorporated has proven difficult (Noble \& Steward 2001), and it has only been utilized for coastal seawater environments of Southern California (Steward et al. 1992a). Thus, TdR may provide only minimal estimates of VP. The primary objective of this inquiry was to evaluate the performance of these 3 methods for estimation of VP within the estuarine waters of the Chesapeake and Delaware Bays.

\section{MATERIALS AND METHODS}

Sampling sites. Water samples were collected in August and December 2001, as well as in March and August 2002 in the Chesapeake and Delaware Bays using 101 Niskin bottles mounted on a CTD rosette. The locations of the sampling sites were Stn CB 858 in Chesapeake Bay $\left(38^{\circ} 58^{\prime} \mathrm{N}, 76^{\circ} 23^{\prime} \mathrm{W}\right)$, and Stns DB 14 $\left(39^{\circ} 48^{\prime} \mathrm{N}, 75^{\circ} 25^{\prime} \mathrm{W}\right)$, and DB $26\left(38^{\circ} 55^{\prime} \mathrm{N}, 75^{\circ} 06^{\prime} \mathrm{W}\right)$ in Delaware Bay. For Stn CB 858, water samples are designated as: $\mathrm{T}=$ surface $(0 \mathrm{~m}) ; \mathrm{M}=\operatorname{midwater}(11$ or $15 \mathrm{~m}) ; \mathrm{B}=$ bottom $(20 \mathrm{~m})$.

Fluorescently labeled tracer virus preparation. Concentration of virioplankton from water samples and subsequent preparation of fluorescently labeled tracer viruses (FLV) were performed in similar fashion to that described by Noble \& Fuhrman (2000). A total of 50 to $100 \mathrm{l}$ of seawater was collected using clean PVC tubing and an industrial diaphragm pump (Jabsco), and pre-filtered with a $25 \mu \mathrm{m}$ wound polypropylene filter into acid-washed polypropylene carboys. Prefiltered seawater was serially filtered through a $0.22 \mu \mathrm{m}$ (Pellicon, Millipore) tangential flow filter (TFF), to remove bacteria and larger organisms, and then through a spiral, $30 \mathrm{kD}$ TFF (Amicon, Millipore), to concentrate the virus-sized fraction into a volume of 21 . Virioplankton in the 21 sample were subsequently concentrated to a volume of ca. $300 \mathrm{ml}$ using a smaller $30 \mathrm{kD}$ TFF (Prep-Scale, Millipore). As recommended in the original method (Noble \& Fuhrman 2000), all further virus concentration steps were completed on ice or in a $10^{\circ} \mathrm{C}$ chilled centrifuge to minimize degradation of viruses during processing.

Prior to further concentration, viral concentrates were filtered once again through a $0.22 \mu \mathrm{m}$ Sterivex syringe filter (Millipore). Then, using a $30 \mathrm{kD}$ centrifugal concentration unit (Centricon-80, Millipore), viral concentrates were reduced to a final volume of ca. $3 \mathrm{ml}$. The nucleic acid stain SYBR Gold, which is supplied from the manufacturer (Molecular Probes) at a concentration of $10000 \times$, was added to each viral concentrate at a final concentration of $25 \times$ and incubated in the dark overnight at $4^{\circ} \mathrm{C}$. Following staining, unbound SYBR Gold was rinsed away (in triplicate) by placing the $3 \mathrm{ml}$ viral concentrate into $30 \mathrm{kD}$ concentration units and adding virus-free ultrafiltrate (UF; seawater which passed through a $30 \mathrm{kD}$ ultrafilter) to a final volume of $15 \mathrm{ml}$ (Centricon-20, Millipore) according to the manufacturer's instructions. After washing, FLVs were resuspended to a final volume of ca. $2 \mathrm{ml}$ in UF and counted according to the method of Chen et al. (2001).

FLV incubation experiments. FLV tracer experiments were performed according to Noble \& Fuhrman (2000). FLV concentrate was added to achieve a viral tracer concentration of ca. $10 \%$ of ambient virus concentration in $250 \mathrm{ml}$ incubations of seawater. As direct enumeration of viruses in water samples was not possible prior to FLV experiments, an ambient concentration of $10^{7}$ viruses $\mathrm{ml}^{-1}$ was assumed for Delaware and Chesapeake Bay samples. Each experiment consisted of an experimental and control treatment performed in duplicate. The heat-treated killed control was made by boiling seawater samples for 20 min then cooling to in situ water temperature in a flow table. Experimental incubations consisted of viral tracer added to $100 \mathrm{ml}$ untreated seawater. Control incubations consisted of viral tracer added to $100 \mathrm{ml}$ heat-treated water samples. All experimental incubations were placed in 
$250 \mathrm{ml}$ polycarbonate bottles (Nalgene); any measurable rate of disappearance of FLV in the control incubation was corrected for in experimental treatment bottles.

VP and removal rates were calculated according to Noble \& Fuhrman (2000). If viral abundance did not change over time, then the removal rate was equal to the production rate (and the equation was not used). For each experiment, initial rates (using the first 2 time points, $t_{0}$ and $t_{1}$ ) and overall rates (using the entire time course of $36 \mathrm{~h}$ ) of production and decay were calculated. In some cases, tracer abundance increased between $t_{0}$ and $t_{1}$. For these cases, tracer abundance at $t_{1}$ was ignored and initial rates were calculated between $t_{0}$ and $t_{2}$.

Bottles were incubated at in situ water temperatures in the dark, and all sub-samples were taken under darkened conditions to prevent photobleaching of SYBR Gold-labeled tracer viruses. At each time point, $15 \mathrm{ml}$ sub-samples of treatment and control incubations were taken in sterile, $15 \mathrm{ml}$ polypropylene tubes. Sub-samples were immediately fixed with a $1 \%$ final concentration of $0.20 \mu \mathrm{m}$ filtered formalin and stored at $4^{\circ} \mathrm{C}$. Slides were made after $6 \mathrm{~d}$ for December 2001 and August 2002 samples and after 18 d for August 2001 and March 2002 samples, and kept at $-20^{\circ} \mathrm{C}$. Due to the use of formaldehyde and storage at $4^{\circ} \mathrm{C}$ (Wen et al. 2004), viral abundances were most likely negatively affected, and resulting abundances, underestimated.

DIL experiments. DIL experiments were modeled after those reported by Wilhelm et al. (2002), with the following modifications. UF water was obtained as described above. A $300 \mathrm{ml}$ water sample was gently vacuum filtered $(<258 \mathrm{~mm} \mathrm{Hg})$ through a $47 \mathrm{~mm}$, $0.20 \mu \mathrm{m}$ pore size polycarbonate filter (Isopore, Millipore). During vacuum filtration, small diameter polyethylene tubing was placed close to, but not touching, the filter, while a peristaltic pump circulated the water sample to prevent clogging and attachment of bacteria to the filter. Sample volume was maintained at ca. $300 \mathrm{ml}$ by adding virus-free UF. Viruses were diluted to ca. 10 to $20 \%$ of ambient abundance using $3 \mathrm{vol}$ of UF. The final $300 \mathrm{ml}$ diluted sample was divided into 3 replicates of $100 \mathrm{ml}$ each, placed in $250 \mathrm{ml}$ polycarbonate bottles, and incubated in the dark at in situ temperatures. Sub-samples $(10 \mathrm{ml})$ from each replicate were fixed in $1 \%$ formalin (as above) and collected every $3 \mathrm{~h}$ over $12 \mathrm{~h}$ for subsequent viral enumeration. VP rates were inferred from the slope of the first-order linear regression line for changes in viral abundance over time. Calculated VP estimates were corrected for the loss of bacterial hosts, i.e. the difference between initial bacterial abundance in incubation flasks and ambient bacterial abundance during vacuum diafiltration.
TdR viral production experiments. VP estimations using TdR were based on Steward et al. (1992a,b). TdR was added at $20 \mathrm{nM}$ using a stock of $81 \mathrm{Ci} \mathrm{mmol}^{-1}$. Incubation time was 2 to $18 \mathrm{~h}$. Dissolved particulate matter was separated in the 3 macromolecular viral pools: viral DNA, viral RNA, and viral protein. Calculations of VP rates were computed using a high $(2.1 \times$ $10^{21}$ viruses $\mathrm{mol}^{-1} \mathrm{TdR}$ incorporated) and low conversion factor $\left(6.17 \times 10^{20}\right.$ viruses $\mathrm{mol}^{-1} \mathrm{TdR}$ incorporated $)$ (Steward et al. 1992a, 1996, Noble \& Steward 2001).

Viral and bacterial direct counting. A modified method of Chen et al. (2001) was used to determine viral abundances in water samples. For total viral counts, a $1.5 \mathrm{ml}$ sub-sample was filtered through a $25 \mathrm{~mm}, 0.02 \mu \mathrm{m}$ filter (Anodisc, Whatman), backed with both a $0.20 \mu \mathrm{m}$ filter (Supor, Pall Gelman) and an extra thick glass fiber filter (GFF) at approximately $20 \mathrm{kPa}$ in a vacuum manifold. Filters were stained for 15 min in the dark with a final concentration of $2.5 \times$ SYBR Gold (Molecular Probes), which is supplied from the manufacturer as a $10000 \times$ concentrate. Ten fields from each filter were selected randomly on a Zeiss Axioscop-2 epifluorescence microscope with a $100 \times$ Plan NEOFLUAR oil objective, under FITC excitation. Each field was digitally captured using an ORCA-ER camera (Hamamatsu) in a 12 bit TIFF format and enumerated using FoVea Pro (Reindeer Software) in conjunction with Adobe Photoshop. Viruses were identified and differentiated from bacteria by relative size and fluorescence intensity. FLV tracer abundance was determined by filtering ca. $10 \mathrm{ml}$ of either control or treatment sub-samples as described above. Because viral abundance in DIL experiments was reduced to ca. $10 \%$ of ambient viral concentration, it was also necessary to filter $10 \mathrm{ml}$ of each sub-sample for viral enumeration.

Calculations and statistics. For calculations of viralmediated bacterial mortality (VMM), VP estimates were divided by a burst size conversion factor of 50 viruses produced per lytic event. In similar studies where in situ burst size was not estimated directly by TEM (Weinbauer et al. 1993), an assumed size of 50 viruses per burst has commonly been used (for review see Wommack \& Colwell 2000). Use of higher burst sizes results in more conservative estimates of VMM. To ensure that loss of viruses due to formaldehyde and $4^{\circ} \mathrm{C}$ storage had minimal effects on estimates of VP, viral abundances were corrected according to the viral decay model of Wen et al. (2004). VP estimates that changed significantly with this correction $(p<0.05)$ were eliminated from the analysis. Comparisons of mean VP estimates from the 3 methods were evaluated by 1-way analysis of variance (ANOVA), followed by Tukey's multiple comparison test. VP data from FLV experiments were further analyzed by multi-factor ANOVA. 


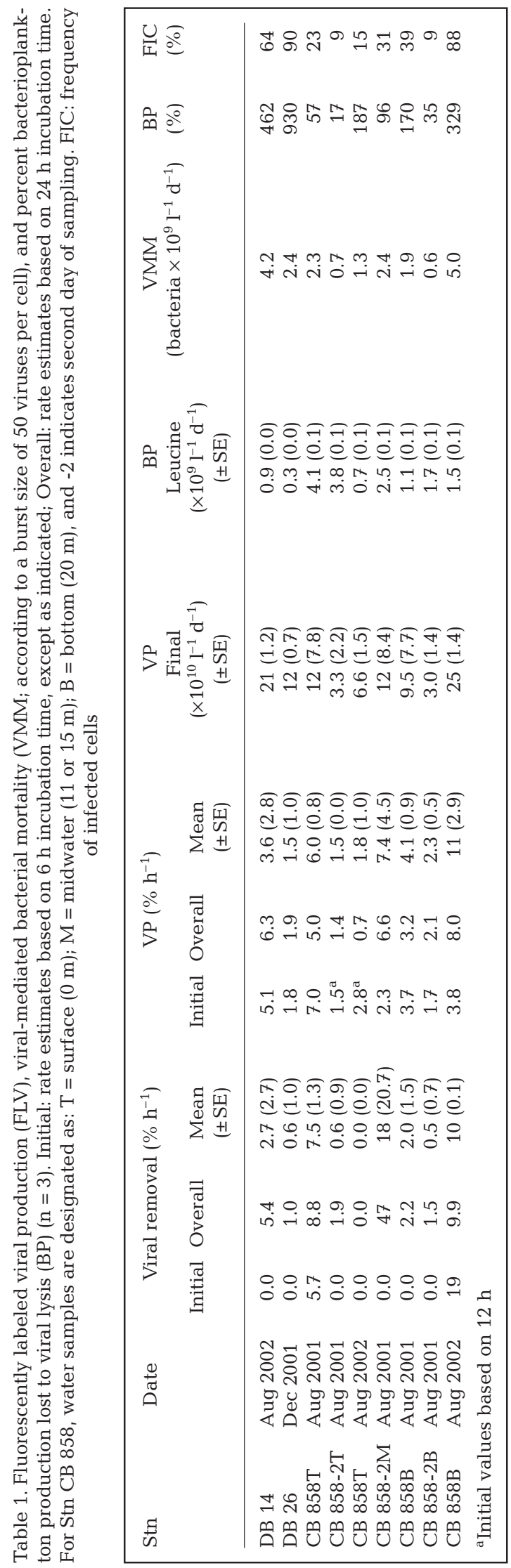

Bacterial production. Bacterial cells produced per hour were estimated by the leucine-incorporation method (Kirchman 2001), with samples processed by centrifugation (Smith \& Azam 1992) in triplicate. The added leucine concentration was $20 \mathrm{nM}$, and the incubation time was 20 to $40 \mathrm{~min}$. An index of the bacterial growth rate was obtained by dividing leucine-incorporation rates (bacterial production, BP) by bacterial abundance, which was measured by fluorescence microscopy (Porter \& Feig 1980).

\section{RESULTS}

\section{Station characteristics}

Dates for sampling and station locations were chosen to estimate VP over the annual range of surface water temperatures and the gradient of salinities known to occur in these estuaries. Surface water temperatures for March, December, and August sampling times were ca. 8,13 , and $27^{\circ} \mathrm{C}$, respectively. Salinities in Delaware Bay were oligohaline (0.2 to $1.0 \%$ ) at Stn DB 14 and polyhaline (30 to $32 \%$ ) at Stn DB 26. Stn CB 858 in Chesapeake Bay was mesohaline (12 to $15 \%$ ).

\section{Fluorescently labeled viruses}

VP estimates using the FLV method for Delaware Bay water samples ranged from $12 \times 10^{10}$ to $21 \times 10^{10}$ viruses $\mathrm{l}^{-1} \mathrm{~d}^{-1}$. Samples from Chesapeake Bay ranged from 3 to $25 \times 10^{10}$ viruses $\mathrm{l}^{-1} \mathrm{~d}^{-1}$ (Table 1 ). In all cases, over the $36 \mathrm{~h}$ incubation, abundance of fluorescently labeled tracer viruses declined, while abundance of total viruses increased, especially during the initial $12 \mathrm{~h}$ of the incubation. On the occasional instances when tracer abundance increased, actual values were assumed to be no higher than initial tracer abundance. In most instances, VP estimates from the initial 6 to $12 \mathrm{~h}$ of the incubation agreed with estimates calculated over the entire $36 \mathrm{~h}$ experiment (Table 1). An advantage of the FLV method is the ability to estimate both VP and viral loss within the same experiment. In most instances, loss rate estimates were lower than production estimates. However, because of large errors associated with these estimates, no significant difference was apparent between viral loss and VP. In August 2002, VP in surface waters at Stns DB 14 and DB 26 in Delaware Bay exceeded that in surface waters at Stn CB 858 in Chesapeake Bay $(p<0.05)$. Significant differences in VP rates over a depth profile were apparent at Stn CB 858 in August 2002 ( $p<0.05$ ), with production in bottom water samples $(20 \mathrm{~m}$, Stn CB 858B) significantly higher than middle (11 or 15 m, Stn 
CB $858 \mathrm{M})$ and surface water samples $(0 \mathrm{~m}$, Stn CB 858T) $(\mathrm{p}<0.05)$ (Table 1). Bottom waters at this station were anoxic in August 2002. Although it would have been preferable to maintain bottom water samples under anoxic conditions, no such facilities were available aboard ship. Nevertheless, BP estimates by ${ }^{3} \mathrm{H}$-leucine incorporation from these samples were comparable to oxic water samples collected from shallower depths (Table 1).

From VP rates it is possible to predict the rate of VMM within a given microbial community. At Stn CB 858, using a burst size conversion value of 50 viruses per infection event, between $0.6 \times 10^{9}$ and $5 \times 10^{9}$ bacteria $\mathrm{l}^{-1} \mathrm{~d}^{-1}$ were consumed by viral lysis, and in August 2002 the VMM observed in bottom waters was more than double that recorded for shallower depths $(p<0.05)$ (Table 1). A similar level of predicted bacterioplankton mortality was seen in Delaware Bay water samples $\left(2.4 \times 10^{9}\right.$ to $4.2 \times 10^{9}$ bacteria $\mathrm{l}^{-1} \mathrm{~d}^{-1}$ ). Dividing VMM estimates by $\mathrm{BP}$ yields an estimate of the proportion of daily BP consumed by viral lysis. From a burst size of 50 viruses per infection event, 17 to $930 \%$ of BP was consumed by viral lysis in water samples analyzed by the FLV method.

Alternatively, it is possible to calculate the daily frequency of infected bacterial cells by dividing ambient bacterial abundance by the VMM rate. At a burst size of 50 viruses per bacterial cell, 9 to $90 \%$ of bacteria were calculated to be infected using FLV VP data (Table 1). Overall, the frequency of infected cells (FIC) in Delaware Bay water samples was higher than that in Chesapeake Bay water samples ( $p<0.05, t$-test, Type III, 2-tailed). Specifically, the mean FIC of experiments at Stns DB 14 and DB 26 was double that recorded for experiments at Stn CB 858, 68 versus 36\%, respectively (Table 1).

\section{Dilution}

During vacuum diafiltration, bacterial loss was as little as $48 \%$ (Stn DB 26, August 2002) and as much as $94 \%$ (Stn CB 858B, August 2002) of ambient bacterioplankton abundance (data not shown). To account for the impact of bacterial loss on VP estimates, initial VP estimates were multiplied by the inverse of the percent bacteria remaining in the incubation. In the case of DIL experiments conducted at Stn CB 858B, this increased initial VP estimates 17-fold. Estimates of VP for Delaware Bay water samples ranged from 0.5 to $3 \times 10^{10}$ viruses $\mathrm{l}^{-1} \mathrm{~d}^{-1}$, while DIL VP estimates for Chesapeake Bay samples ranged from 13 to $15 \times 10^{10}$ viruses $\mathrm{l}^{-1} \mathrm{~d}^{-1}$ (Table 2). Among these estimates only 1 water sample was significantly different with regard to VP rate. At Stn DB 26 VP in March 2002 significantly exceeded that in August 2002 ( $p<0.05)$. Using a burst size of 50 viruses produced per lytic event and DIL VP numbers, VMM was estimated at between 1.5 and $38 \%$ of daily BP (Table 2). Calculated daily FIC was between 1.7 and $3.7 \%$ for Delaware Bay stations and 30 to $54 \%$ for the Chesapeake Bay station water samples.

\section{Thymidine incorporation}

VP estimates calculated from incorporation of ${ }^{3} \mathrm{H}-$ labeled thymidine into the viral fraction of seawater ranged from $2 \times 10^{9}$ (Stn CB 858B) to $25 \times 10^{9}$ viruses $1^{-1}$ $\mathrm{d}^{-1}$ (Stn CB 858-2T) using the low conversion factor and 6 to $83 \times 10^{9}$ viruses $\mathrm{l}^{-1} \mathrm{~d}^{-1}$ using the high conversion factor (Table 3). At Stn CB 858, VP measurements determined using TdR (Fig. 1) varied between sampling dates and over the depth profile. On 16 August 2001, VP was significantly lower than that on 17 August 2001 ( $p<0.01$ ) (Fig. 1A). In surface waters, VP was considerably higher $(p<0.01)$ than in mid- and bottom waters on 17 August (Fig. 1A). VMM estimates using a burst size of 50 gave TdR VP values ranging from $3-15 \%$ (low conversion factor) to $10-49 \%$ (high conversion factor) of the BP (Table 3 ).

\section{Comparison of methods for estimation of viral production}

Estimates of VP using FLV significantly exceeded those from DIL for samples taken at the same time at Stns DB 14 and DB 26 ( $\mathrm{p}<0.05)$. However, no significant differences were detected between FLV and DIL VP estimates at Stns CB 858T and CB 858B for the August 2002 water samples ( $p>0.05$ ) (Fig. 1B). Similarly, side-by-side estimates of VP using FLV and TdR methods showed FLV-based VP estimates to be significantly higher than TdR estimates based on the low 
Table 3. Thymidine (TdR) incorporation approach: viral production (VP) $(\mathrm{n}=3)$, turnover time, viral-mediated bacterial mortality (VMM; according to a burst size of 50 viruses per cell), and percent bacterioplankton production lost to viral lysis (BP)

\begin{tabular}{|c|c|c|c|c|c|c|c|c|}
\hline \multirow[t]{2}{*}{ Stn } & \multirow[t]{2}{*}{ Date } & \multirow{2}{*}{$\begin{array}{l}\text { Depth } \\
\text { (m) }\end{array}$} & \multicolumn{3}{|c|}{ Low conversion factor } & \multicolumn{3}{|c|}{ High conversion factor } \\
\hline & & & $\begin{array}{c}\mathrm{VP} \\
\left(\times 10^{10} \mathrm{l}^{-1} \mathrm{~d}^{-1}\right)( \pm \mathrm{SE})\end{array}$ & $\begin{array}{c}\text { VMM } \\
\left(\text { bacteria } \times 10^{9} \mathrm{l}^{-1} \mathrm{~d}^{-1}\right)\end{array}$ & $\begin{array}{l}\mathrm{BP} \\
(\%)\end{array}$ & $\begin{array}{c}\text { VP } \\
\left(\times 10^{10} \mathrm{l}^{-1} \mathrm{~d}^{-1}\right)( \pm \mathrm{SE})\end{array}$ & $\begin{array}{c}\text { VMM } \\
\left(\text { bacteria } \times 10^{9} \mathrm{l}^{-1} \mathrm{~d}^{-1}\right)\end{array}$ & $\begin{array}{l}\text { BP } \\
(\%)\end{array}$ \\
\hline \multirow[t]{3}{*}{ CB 858} & 16 Aug 2001 & 0 & $0.9(0.1)$ & 0.2 & 4.3 & $2.8(0.4)$ & 0.6 & 14 \\
\hline & & 11 & $0.5(0.1)$ & 0.1 & 4.6 & $1.7(0.3)$ & 0.3 & 15 \\
\hline & & 20 & $0.2(0.1)$ & 0.0 & 3.1 & $0.6(0.2)$ & 0.1 & 10 \\
\hline \multirow[t]{3}{*}{ CB 858-2 } & 17 Aug 2001 & 0 & $2.6(0.3)$ & 0.5 & 13 & $8.3(0.9)$ & 1.7 & 43 \\
\hline & & 15 & $1.1(0.1)$ & 0.2 & 8.4 & $3.4(0.2)$ & 0.7 & 27 \\
\hline & & 20 & $1.3(0.1)$ & 0.3 & 15 & $4.2(0.5)$ & 0.8 & 49 \\
\hline
\end{tabular}

conversion factor $(\mathrm{p}<0.05)$. In contrast, TdR VP estimates using the high conversion factor were not significantly different from FLV estimates in the same water sample ( $\mathrm{p}>0.05)$ (Fig. 1A). FLV measurements remained stable over the 2 sampling days (16 and 17 August 2001), whereas TdR showed significantly higher VP on Day 2.
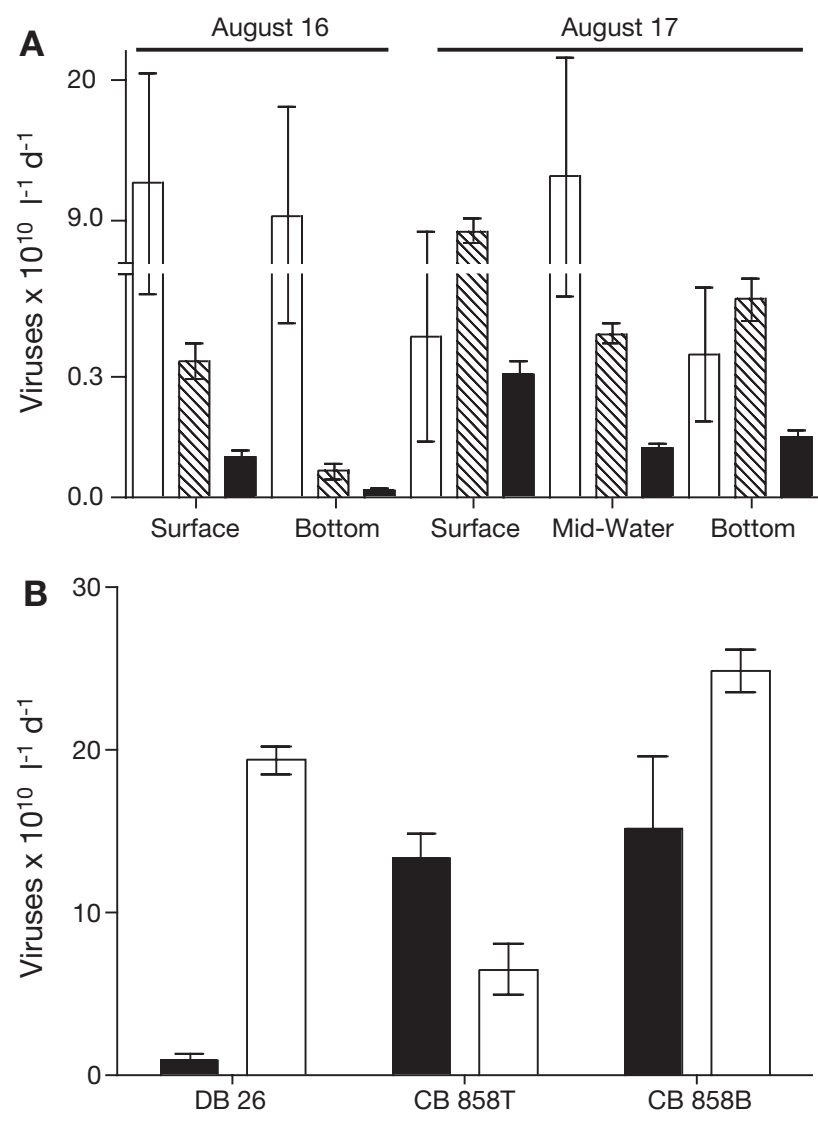

Fig. 1. Comparisons of fluorescently labeled viruses (FLV), dilution (DIL), and thymidine incorporation (TdR) methods. (A) FLV versus TdR at Stn CB 858 (open bars: FLV; hatched bars: TdR high conversion factor; black bars: TdR low conversion factor). (B) FLV versus DIL in August 2002 (open bars:

FLV; black bars: DIL; error bars: \pm SE)

\section{DISCUSSION}

\section{Method evaluation}

To date, published estimates of VP have principally come from coastal oceanic environments; however, similar studies of VP by FVIC and grazing rates have been applied to freshwater ecosystems (Hennes \& Simon 1995, Weinbauer \& Höfle 1998a,b, Bettarel et al. 2005). There is no reason to assume that our results for estuarine waters would be any different for freshwater environments. The VP rates reported here represent the largest dataset for eutrophic estuarine environments, and are among the highest values ever reported, especially for FLV estimates. VP estimates over a depth gradient in the hyper-eutrophic and stratified freshwater lake Plußsee ranged from $0.2 \times 10^{10}$ to $1.9 \times 10^{10}$ viruses $\mathrm{l}^{-1} \mathrm{~d}^{-1}$ using the FVIC method (Weinbauer \& Höfle 1998b). VP estimates based on measurements of viral decay ranged from $7 \times 10^{10}$ to $155 \times 10^{10}$ viruses $\mathrm{l}^{-1} \mathrm{~d}^{-1}$ in coastal Norwegian waters (Heldal \& Bratbak 1991) and $17 \times 10^{10}$ viruses $\mathrm{l}^{-1} \mathrm{~d}^{-1}$ in the Bay of Århus, Denmark (Bratbak et al. 1992). However, as the aggregate results of this study demonstrate, a meaningful comparison of reported VP rates between different marine environments is complicated by the inherent variability between methods. Large discrepancies between methods which hinder efforts to constrain the impact of viral infection on microbial loop processes prompted this study as well as a report by Weinbauer et al. (2002). In the Baltic, Mediterranean, and North Seas, the FVIC method consistently underestimated the level of VMM compared to the DIL method. This consistent finding prompted upward revision of the conversion factor relating the FVIC to FIC (Weinbauer et al. 2002).

The 3 incubation-based methods evaluated here were appreciably different with regards to accuracy and ease of implementation. The FLV method was labor intensive and in some cases, e.g. water samples from Stn DB 26 in March 2002, yielded implausible 
results for the estuarine waters studied here, which were excluded from the data analysis. FLV requires lengthy preparation (2 to $3 \mathrm{~d}$ ) of a labeled viral concentrate for use as a tracer within samples. Preparing the tracer from the same water sample to be assayed ensures that tracer viruses will respond in a similar manner to ambient viruses in experimental incubations (Noble \& Fuhrman 2000). In the case of these experiments, performed during short oceanographic research cruises, it was not logistically possible to prepare a viral tracer from exactly the same water sample as the incubation experiment. Instead, tracer viral concentrates were prepared from water samples collected at the same station on a previous date. Once prepared, it was necessary to enumerate viral abundance within the tracer, which required an extensive amount of microscopy.

Because it is difficult to enumerate viral abundance on board a ship, it was necessary to prepare the tracer in a shore-side laboratory. This limitation also prevented estimation of ambient viral abundance within water samples prior to addition of tracer viruses. To overcome this, we assumed an ambient viral abundance of $10^{7}$ viruses $\mathrm{ml}^{-1}$ and added tracer to a concentration of $10^{6}$ viruses $\mathrm{ml}^{-1}$. In all cases, assumed viral abundance was equal to or lower than ambient viral abundance, сa. 0.1 to $3 \times 10^{8}$ viruses $\mathrm{ml}^{-1}$. This approach prevented addition of tracer in excess of the recommended $10 \%$ of ambient viral abundance. However, it could have contributed to error within the experiment. In our experience, the accuracy of viral enumeration declines in samples with low viral abundance. This was certainly true for FLV abundance within seawater incubations. The inability to accurately assess ambient viral abundance in the field is problematic for the application of the FLV method to a broad range of aquatic environments.

The FLV method also requires maintenance and sampling of a heat-killed control in addition to treatment samples. Each incubation bottle was replicated and sub-sampled 5 times. Including viral tracer, total viruses, and ambient viral counts, 34 epifluorescence microscopic enumerations were performed for each FLV experiment. By any account this is a high number of microscopic enumerations for a single experiment. In comparison, the DIL method only requires 17 enumerations and has higher replication. Furthermore, tracer virus fluorescence within sub-samples from control and treatment incubations were often weak and seemed to fade rapidly, even when samples or prepared slides were stored at $-20^{\circ} \mathrm{C}$.

Despite the inherent variability and technical difficulties of FLV, differences in VP estimates between samples likely reflect true variability in viral infection and lysis. Correlation analysis of FIC estimates with

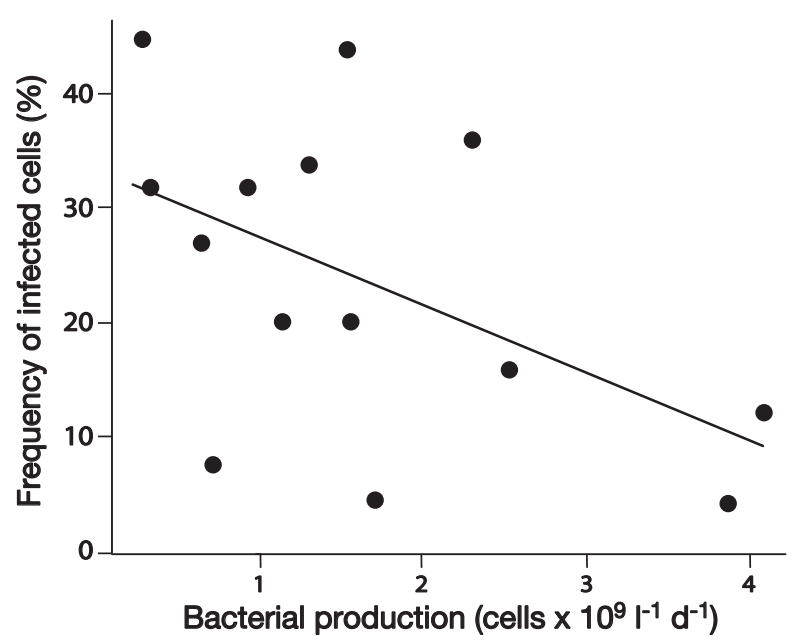

Fig. 2. Relationship of frequency of infected cells to bacterial production. Solid line represents the linear regression of data $(\bullet)$

BP indicates a negative relationship (Fig. 2). Thus, fewer infected cells occurred at times of high BP. Although a different method was used to estimate VP, Winter et al. (2004) observed this same relationship for North Sea microbial communities. In contrast, Hwang \& Cho (2002) found a positive and significant correlation between viral and bacterial turnover time for published estimates and their estimates in water samples from the East Sea, Korea. Intuitively, the growth rate of viral and bacterial communities should be linked, as VP ultimately depends on the metabolic activity of the host (Middelboe 2000). A similar, but not significant, trend in the relationship of viral and bacterial turnover was seen for FLV VP estimates (data not shown).

Of the 3 methods tested, DIL proved to be least difficult in design; however, vacuum diafiltration of viruses from water samples using virus-free seawater tended to provide inconsistent incubation conditions, leading to poor replicability, e.g. $\sim 73 \%$ of the bacterial cells were lost during diafiltration. To account for this loss of bacteria, VP rates were adjusted by multiplying the slope of the first-order regression line by the inverse of the proportion of remaining bacteria. In some cases the bacterial loss correction factor was almost 17 -fold the original rate. Another drawback of the DIL method was the 2 to $3 \mathrm{~h}$ processing time to reduce viral abundance using vacuum filtration through a $0.22 \mu \mathrm{m}$ filter. Due to this time limitation, the experiment was not truly replicated, as each replicate incubation was simply a $100 \mathrm{ml}$ sub-sample of a single $300 \mathrm{ml}$ viral-reduced water sample. This was in keeping with the method originally outlined by Wilhelm et al. (2002). Recently, we improved the DIL method by using tangential flow 
diafiltration, which reduces the loss of bacteria and demonstrates this approach to be a stable and reliable means of measuring VP (Winget et al. 2005, this issue). Of all VP methods, the FLV and DIL approaches are the most direct and require only an assumed average burst size to estimate the potential level of VMM. In 2 out of 5 concurrent experiments, VP estimates obtained with FLV and DIL were not statistically different from each other. In the other 3 experiments, DIL estimates were significantly lower and thus more conservative than corresponding FLV estimates.

Although arguably the most precise method used in this study, the TdR method showed high variability in other examined environments (Steward et al. 1992b). TdR requires the use of a large and poorly constrained conversion factor for estimation of VP from radioactive decay. To date, all reported estimates of VP based on TdR incorporation used conversion factors estimated from experiments in Californian coastal seawater (Steward et al. 1992a), likely due to the difficulty of performing independent calibration experiments. Because conversion factors have not been derived for a range of aquatic environments, the general applicability of the original Steward et al. (1992a) factor is not known (G. F. Steward pers. comm.). Furthermore, given that bacteriophages can carry genes for de novo nucleotide synthesis and recycle degraded host nucleic acid (Miller et al. 2003) and that RNA-containing viruses would not be labeled, the TdR technique can at best provide only a lower limit estimate for VP. Nevertheless, comparison of the FLV and TdR approaches demonstrates that when the high conversion factor $\left(2.1 \times 10^{21}\right.$ viruses $\mathrm{mol}^{-1} \mathrm{TdR}$ incorporated) is used VP estimates tend to be in closer agreement.

Accurate derivation of conversion factors is confounded by limited knowledge of virioplankton genetic content and in situ isotope dilution. Noble \& Steward (2001) considered the theoretical accuracy of empirically derived conversion factors assuming that an average virioplankton genome contains $50 \mathrm{~kb}$ of dsDNA with a $\mathrm{G}+\mathrm{C}$ content of $50 \%$ and that overall TdR isotope dilution is 42 -fold for viruses (i.e. 5 -fold for bacteria and 8.3-fold for viruses). From these assumptions, a theoretically derived conversion factor was similar to the high conversion factor of $2.1 \times 10^{21}$ viruses $\mathrm{mol}^{-1}$ TdR. Perhaps the best approach for determining an ideal TdR incorporation conversion factor would be to apply independent means for estimation of VP in the same water sample, e.g. the conversion of FVIC to FIC (Weinbauer et al. 2002).

In light of recent data that demonstrate a significant loss of virus particles within aldehyde-fixed or unfixed water samples stored at $4^{\circ} \mathrm{C}$ (Brussaard 2004, Wen et al. 2004), proper storage of water samples is critical for accurate viral enumeration. As our present study was conducted prior to these reports, all samples were fixed and stored at $4^{\circ} \mathrm{C}$. To test whether VP estimates from the FLV and DIL were affected by refrigerated storage, viral counts were corrected for storage-related losses according to a decay model presented in Wen et al. (2004). VP estimates based on DIL were unaffected by the correction, and only 4 out of 13 FLV-based estimates changed significantly $(p<0.05)$. Because of this uncertainty, these 4 FLV experiments were removed from the analysis. It is interesting to note that, although immediate freezing in liquid $\mathrm{N}_{2}$ followed by storage at $-80^{\circ} \mathrm{C}$ is the recommended means of storing water samples for viral enumeration, VP estimates were relatively unaffected by storage-related losses of virus particles.

In their current form, all 3 incubation-based VP methods appear to have complications. Nevertheless, we believe that with an improvement in the recovery of bacteria and the dilution of viruses, DIL will be the best-suited incubation-based VP method for swift and reliable estimates of VP in the Chesapeake and Delaware Bays (Winget et al. 2005).

\section{Comparisons of viral production in aquatic environments}

\section{Fluorescently labeled viruses}

Previous studies using FLV (Noble \& Fuhrman 2000) found VP ranging from $0.3 \times 10^{10}$ to $2.8 \times 10^{10}$ viruses $l^{-1}$ $\mathrm{d}^{-1}$ in the coastal waters of California. In the eutrophic waters of the Chesapeake and Delaware Bays, FLV showed VP ranging from a reasonable $2.9 \times 10^{10}$ viruses $\mathrm{l}^{-1} \mathrm{~d}^{-1}$ to an unrealistic $48.9 \times 10^{10}$ viruses $\mathrm{l}^{-1}$ $\mathrm{d}^{-1}$. The grand mean (excluding Stn DB 26, March 2002) for FLV VP estimates was $12.9 \pm 6.3 \times 10^{10}$ viruses $\mathrm{l}^{-1} \mathrm{~d}^{-1}$ for estuarine waters. This average is 11-fold higher than average FLV VP estimates for Californian coastal waters. By comparison, mean BP estimates for Delaware and Chesapeake Bays were only 4 -fold higher than mean estimates from the Californian FLV study (Noble \& Fuhrman 2000). One plausible explanation for the disparity between the levels of VP and BP in these 2 environments could be differences in average burst size for a typical viral infection cycle. Higher burst sizes would produce a greater number of viruses for the same level of total viral infection. Alternatively, dramatic differences in viral decay could explain differences in VP between these environments. Lower viral decay, however, does not appear to contribute to higher VP estimates in the Chesapeake and Delaware Bays, as average decay estimates were only double those in the Californian study. Noting the central importance of assumed burst 
size to estimates of VMM, efforts to better constrain this parameter will be critical to more accurately determine the impact of viral infection on microbial loop processes.

\section{Dilution}

Comparison of dilution-based VP estimates from the Chesapeake and Delaware Bays to other marine environments indicates that mean VP in the North Sea (Winter et al. 2004), British Columbia (Wilhelm et al. 2002), and the Peruvian upwelling (Poorvin et al. 2004) are 10-fold lower, and 2- and 3-fold higher, respectively. The large difference between mean VP rates in the North Sea and the Chesapeake and Delaware Bays is attributable to the lower rates observed in offshore stations. Mean Chesapeake and Delaware VP estimates were 900-fold higher than those recorded for an offshore North Sea station, but only 5-fold higher than estimates from a station just off the Dutch coast. Surprisingly, mean BP rate in North Sea water samples was double that estimated for the Chesapeake and Delaware Bays. At first glance, it would appear that viruses have a correspondingly smaller impact on bacterioplankton mortality in the North Sea than do viruses in the estuarine environments of the Chesapeake and Delaware Bays. However, mean FIC estimates were similar in the 2 environments (19\%, present study; 25\%, North Sea water samples). The similarity of FIC estimates between the North Sea and the Chesapeake and Delaware Bays again reflects the central importance of assumed burst size to estimating the impact of viral infection within a microbial community. In their study, Winter et al. (2004) used burst size conversion factors based on microscopic observations of infected bacterioplankton cells. The grand mean burst size estimate for the North Sea water samples was 24 viruses per bacterial cell, whereas a value of 50 viruses per bacterial cell (which was used in this study) would reduce FIC estimates for the North Sea by 2 - to 4 -fold.

In the high-flow tidal environments of the Discovery Passage, British Columbia, Wilhelm et al. (2002) observed that the highest levels of VP occurred during times of turbulent mixing (flood tide), while low flow periods (ebb tide) were characterized by a 3-fold lower VP rate. Here again, environmental characteristics of the water samples appear to correlate with observed VP. Mean estimates during low-flow conditions were equivalent to mean VP in the Chesapeake and Delaware Bays, while VP during flood tide was over 3-fold higher than the mean estimates reported here. Unfortunately, as neither corresponding BP nor FIC estimates are available for the British Columbian or
Peruvian upwelling studies, comparison of the possible impact of viral infection in these 2 environments is not possible.

\section{Thymidine incorporation}

Of the 3 incubation-based approaches evaluated, TdR incorporation has been the most widely applied. Overall, mean BP and TdR-based VP estimates in mesocosms of Southern Californian coastal seawater (Fuhrman \& Noble 1995) were 2- and 3-fold higher than those seen in the Chesapeake Bay, respectively. As these 2 estimates were consistently and similarly higher in the Californian mesocosms, a similar overall level of viral impact on BP would be expected, assuming equivalent burst size. Because only converted values and not absolute incorporation rates are given, interpretations of how differences in VP and BP might reflect more generalized differences between coastal oceanic (Southern California Bight) and estuarine environments (Chesapeake and Delaware Bays) are not possible. As noted by Ducklow (2000), because of inherent imprecision in the determination of conversion factors, BP estimates are uncertain by at least a factor of 2 .

High latitude ocean environments are among the most productive, and exhibit strong seasonal patterns in biological activity. Compared to the Bering and Chukchi Seas (Steward et al. 1996), levels of TdRbased VP and BP estimates in the Chesapeake Bay were 20- and 10-fold higher, respectively. VP and BP for the Arctic study were estimated in mid- to late summer (August to September), well after the peak in phytoplankton production. Although the Chesapeake Bay TdR-based production estimates were also taken in mid-summer (August), the productive season here lasts well into late summer. It is known that viral abundance varies greatly with the progression of the spring algal bloom in the Arctic (Yager et al. 2001), so it is likely that the highest levels of VP occur closer to the decline of the Arctic spring phytoplankton bloom.

Despite the inherent variability between methods, estimates of VP in aquatic environments clearly demonstrate that viral lysis can be a significant factor in bacterioplankton mortality. Methods to estimate bacterioplankton grazing are similarly plagued by inherent methodological variability; nevertheless, the impact of grazing on BP appears to vary with the overall productivity of the marine ecosystem. In low productivity environments most BP is lost to grazing, while in more productive coastal and estuarine environments BP typically exceeds grazing (Strom 2000). Making a conclusion for the impact of viral lysis on BP across a range of aquatic environments is confounded by the 
inexplicable observation that viral lysis often consumes $>100 \%$ of BP (Bratbak et al. 1992, GuixaBoixereu et al. 2002). For the VP rates reported here, 6 of the 14 FLV-based estimates showed $>100 \%$ of BP consumed. In no case did DIL or TdR-based VP estimates exceed corresponding BP. One solution to quantification of the impact of viral infection is to instead calculate the frequency of infected bacteria from VP estimates (M. G. Weinbauer pers. comm. in 2004). This calculation accounts for the size of the bacterial standing stock, which has consistently been shown to correlate strongly with virioplankton abundance (Wommack \& Colwell 2000). Estimates of bacterial infection frequency from DIL-based VP estimates were sensitive enough to demonstrate significant changes in the level of bacterial infection over diel cycles in the North Sea (Winter et al. 2004). Significant advancements in our ability to accurately quantify the impact of viral infection on bacterioplankton mortality in aquatic ecosystems will come through continuing methodological improvements to estimation of VP and a better understanding of the in situ nature of the virus-host life cycle, especially the parameter of burst size.

Acknowledgements. We thank the crew of the RV 'Cape Henlopen' for assistance with sample collection and D. M. Winget for sharing unpublished results. R.R.H. thanks K. M. Ritalahti and J. R. Cole for valuable comments and suggestions. This research was supported in part by National Science Foundation Grants MCB-0132070 to K.E.W. and OCE-9908808 to D.L.K.

\section{LITERATURE CITED}

Bettarel Y, Sime-Ngando T, Bouvy M, Arfi R, Amblard C (2005) Low consumption of virus-sized particles by heterotrophic nanoflagellates in two lakes of the French Massif Central. Aquat Microb Ecol 39:205-209

Binder B (1999) Reconsidering the relationship between virally induced bacterial mortality and frequency of infected cells. Aquat Microb Ecol 18:207-215

Bratbak G, Heldal M, Thingstad TF, Riemann B, Haslund OH (1992) Incorporation of viruses into the budget of microbial C-transfer. A first approach. Mar Ecol Prog Ser 83:273-280

Brussaard CPD (2004) Optimization of procedures for counting viruses by flow cytometry. Appl Environ Microbiol 70: 1506-1513

Chen F, Lu JR, Binder B, Liu YC, Hodson RE (2001) Application of digital image analysis and flow cytometry to enumerate marine viruses stained with SYBR Green. Appl Environ Microbiol 67:539-545

Ducklow H (2000) Bacterial production and biomass in the oceans. In: Kirchman DL (ed) Microbial ecology of the oceans. John Wiley \& Sons, New York, p 35

Fuhrman JA (1987) Close coupling between release and uptake of dissolved free amino acids in seawater studies by an isotope dilution approach. Mar Ecol Prog Ser 37:45-52

Fuhrman JA (1992) Bacterioplankton roles in cycling of organic matter: the microbial food web. In: Falkowski PG, Woodhead AD (eds) Primary productivity and biogeo- chemical cycles in the sea. Plenum Press, New York, p 361-383

Fuhrman JA, Noble RT (1995) Viruses and protists cause similar bacterial mortality in coastal seawater. Limnol Oceanogr 40:1236-1242

Fuhrman JA, Suttle CA (1993) Viruses in marine planktonic systems. Oceanography 6:50-62

Glibert PM (1982) Regional studies of daily, seasonal and size fraction variability in ammonium remineralization. Mar Biol 70:209-222

Guixa-Boixereu N, Vaque D, Gasol JM, Sanchez-Camara J, Pedros-Alio C (2002) Viral distribution and activity in Antarctic waters. Deep-Sea Res II 49:827-845

Heldal M, Bratbak G (1991) Production and decay of viruses in aquatic environments. Mar Ecol Prog Ser 72:205-212

Hennes KP, Simon M (1995) Significance of bacteriophages for controlling bacterioplankton growth in a mesotrophic lake. Appl Environ Microbiol 61:333-340

Hwang CY, Cho BC (2002) Virus-infected bacteria in oligotrophic open waters of the East Sea, Korea. Aquat Microb Ecol 30:1-9

Kirchman D (2001) Measuring bacterial biomass production and growth rates from leucine incorporation in natural aquatic environments. Methods Microbiol 30:227-237

Landry MR (1993) Estimating rates of growth and grazing mortality of phytoplankton by the dilution method. In: Kemp PF, Sherr BF, Sherr EB, Cole JJ (eds) Handbook of methods in aquatic microbial ecology. Lewis Publishers, Boca Raton, FL, p 715-722

Middelboe $M$ (2000) Bacterial growth rate and marine virus-host dynamics. Microb Ecol 40:114-124

Middelboe M, Jorgensen NOG, Kroer N (1996) Effects of viruses on nutrient turnover and growth efficiency of noninfected marine bacterioplankton. Appl Environ Microbiol 62:1991-1997

Miller ES, Kutter E, Mosig G, Arisaka F, Kunisawa T, Ruger W (2003) Bacteriophage T4 genome. Microbiol Mol Biol Rev 67:86-156

Noble RT, Fuhrman JA (2000) Rapid virus production and removal as measured with fluorescently labeled viruses as tracers. Appl Environ Microbiol 66:3790-3797

Noble RT, Steward GF (2001) Estimating viral proliferation in aquatic samples. In: Paul JH (ed) Methods in microbiology, Vol 30. Plenum Press, New York, p 67-82

Poorvin L, Rinta-Kanto JM, Hutchins DA, Wilhelm SW (2004) Viral release of iron and its bioavailability to marine plankton. Limnol Oceanogr 49:1734-1741

Porter KG, Feig YS (1980) The use of DAPI for identifying and counting aquatic microflora. Limnol Oceanogr 25:943-948

Proctor LM, Fuhrman JA (1990) Viral mortality of marine bacteria and cyanobacteria. Nature 343:60-62

Smith DC, Azam F (1992) A simple, economical method for measuring bacterial protein synthesis rates in seawater using (super) ${ }^{3} \mathrm{H}$-leucine. Mar Microb Food Webs 6: 107-114

Steward GF, Wikner J, Cochlan WP, Smith DC, Azam F (1992a) Estimation of virus production in the sea. I. Method development. Mar Microb Food Webs 6:57-78

Steward GF, Wikner J, Cochlan WP, Smith DC, Azam F (1992b) Estimation of virus production in the sea. II. Field results. Mar Microb Food Webs 6:79-90

Steward GF, Smith DC, Azam F (1996) Abundance and production of bacteria and viruses in the Bering and Chukchi Seas. Mar Ecol Prog Ser 131:287-300

Strom SL (2000) Bacterivory: interactions between bacteria and their grazers. In: Kirchman DL (ed) Microbial ecology of the oceans. John Wiley \& Sons, New York, p 351-386 
Suttle CA, Chan AM (1994) Dynamics and distribution of cyanophages and their effect on marine Synechococcus spp. Appl Environ Microbiol 60:3167-3174

Suttle CA, Chen F (1992) Mechanisms and rates of decay of marine viruses in seawater. Appl Environ Microbiol 58: 3721-3729

Waterbury JB, Valois FW (1993) Resistance to co-occurring phages enables marine Synechococcus communities to coexist with cyanophages abundant in seawater. Appl Environ Microbiol 59:3393-3399

Weinbauer MG, Höfle MG (1998a) Size-specific mortality of lake bacterioplankton by natural virus communities. Aquat Microb Ecol 15:103-113

Weinbauer MG, Höfle MG (1998b) Significance of viral lysis and flagellate grazing as factors controlling bacterioplankton production in a eutrophic lake. Appl Environ Microbiol 64:431-438

Weinbauer MG, Fuks D, Peuzzi P (1993) Distribution of viruses and dissolved DNA along a coastal trophic gradient in the northern Adriatic Sea. Appl Environ Microbiol 59:4074-4082

Weinbauer MG, Winter C, Höfle MG (2002) Reconsidering transmission electron microscopy based estimates of viral infection of bacterio-plankton using conversion factors derived from natural communities. Aquat Microb Ecol 27: 103-110

Editorial responsibility: Gunnar Bratbak, Oslo, Norway
Wen K, Ortmann AC, Suttle CA (2004) Accurate estimation of viral abundance by epifluorescence microscopy. Appl Environ Microbiol 70:3862-3867

Wilhelm SW, Brigden SM, Suttle CA (2002) A dilution technique for the direct measurement of viral production: a comparison in stratified and tidally mixed coastal waters. Microb Ecol 43:168-173

Winget DM, Williamson KE, Helton RR, Wommack KE (2005) Tangential flow diafiltration: an improved technique for estimation of virioplankton production. Aquat Microb Ecol 41:221-232

Winter C, Herndl GJ, Weinbauer MG (2004) Diel cycles in viral infection of bacterioplankton in the North Sea. Aquat Microb Ecol 35:207-216

Wommack KE, Colwell RR (2000) Virioplankton: viruses in aquatic ecosystems. Microbiol Mol Biol Rev 64:69-114

Wommack KE, Hill RT, Kessel M, Russek-Cohen E, Colwell RR (1992) Distribution of viruses in the Chesapeake Bay. Appl Environ Microbiol 58:2965-2970

Wommack KE, Hill RT, Muller TA, Colwell RR (1996) Effects of sunlight on bacteriophage viability and structure. Appl Environ Microbiol 62:1336-1341

Yager PA, Connelly TL, Mortazavi B, Wommack KE, Bano N, Bauer JE, Opsahl S, Hollibaugh JT (2001) Dynamic bacterial and viral response to an algal bloom at subzero temperatures. Limnol Oceanogr 46:790-801

Submitted: March 23, 2005; Accepted: October 4, 2005 Proofs received from author(s): December 13, 2005 